\title{
水銀法によるたばこ刻みの見掛け密度の測定法
}

\author{
日本専売公社中央研究所片山良徳 - 清水幸夫 \\ 東京工業大学工学部 清水二郎
}

\section{A "MERCURY DISPLACEMENT" METHOD FOR MEASUREMENT OF THE APPARENT DENSITY OF CUT TOBACCO}

\author{
By Yoshinori Katayama*, Yukio Shimizu* and Jiro Shimizu** \\ * (Central Research Institute, The Tobacco \& Salt Public \\ Corporation, Umegaoka, Midori-ku, Yokohama, Japan) \\ ** (Faculty of Engineering, Tokyo Institute of Technology, \\ Ookayama, Meguro-ku, Tokyo, Japan)
}

The apparent density of cut tobacco is one of the most important physical properties, because it has a high correlation to the bulkiness (Filling value) relating closely to the reduction of materials in cigarette production. In addition, it is related to the burning characteristics of cigarettes which have a great influence on the taste and aroma of smoke, and to the conditions of separating, transporting and drying processes of cigarette making. However, the conventional measurement method (the oil impregnation method) has the disadvantages of long operating time. For a rapid and convenient measurement of apparent density, the "mercury displacement" method was investigated using the large mercury surface tension. And the results obtained are as follow.

1) The apparent specific volume of cut tobacco in the pressure range of about 200 to $300 \mathrm{~g}-\mathrm{f} /$ $\mathrm{cm}^{2}$ was recognized to be in the nearly costant state, though it slightly decreased with the increase in pressure. The apparent density of each sample obtained under the pressure of $250 \mathrm{~g}-\mathrm{f} / \mathrm{cm}^{2}$ agreed with the value by other methods, and it was adopted as the standard pressure in this method.

2) Under the standard pressure, it was confirmed experimentally that the mercury would not enter into the concave surface and the pore of diameter less than $60 \mu \mathrm{m}$. And the pore of diameter above $60 \mu \mathrm{m}$ could not be observed in the surface of ordinary cut tobacco.

3) The values of apparent density and their accuracy obtained by this standardized method were almost the same as those obtained by the conventional method. The time required for this operation was about $15 \mathrm{~min}$, which was one-third for the time of the conventional method.

4) The apparent density of cut tobacco consisting of the ordinary grain size distribution could be measured exactly by the pressure of $250 \mathrm{~g}-\mathrm{f} / \mathrm{cm}^{2}$ and sample weight of $1-2 \mathrm{~g}$ (in case of $25 \mathrm{~cm}^{3}$ sample cell) as the standardized procedure.

(Received July 15, 1982)

\section{1. 緒毫}

たばこの刻みは多孔質材料であり，その多孔性を表す 兒掛け密度は，原料の節約に関係し，また，たばこの味 や香りに関与する燃焼性や製造工程での分離，輸送，乾 燥などに関係する重要な物理的性筫の一つである。しか し，その見挂的密度の測定法について検討した赫告”は
少なく，しかもその方法は繁雑であるので簡便な測定法 が強く要望されている。

たばこの葉の場合は，ある程度の大きさをあった葉片 を採取できるので，紙の測定法 ${ }^{2)}$ 之同様に厚さの測定か ら単位面皘重量よの関係で容易に見掛け密度を求めるこ とができる。しかし，たばこの刻みは細かく切られ，し 加あ熱などで好理されることが多く，形は複雑であり， 
紙に類似した方法を刻みに適用することは実際上困難で ある。

現在ある方法には、刻みの細孔に真空油を含浸させて その含浸した重量から見掛け密度を求める油含浸法 ${ }^{1)}$ か あるが，この方法では試料表面の油膜の遠心力による除 去操作と真密度の測定などの操作があって繁雑となり, 測定に時間を要する欠点がある。

そこで，刻みの見掛け密度を簡便に測定することを目 的として，水銀の表面張力が大きいととを利用した紙の 厚さ，見掛け密度の簡便な測定法 ${ }^{3}$ (4) ヘリウムー水銀法に よる全細孔容積の測定法 ${ }^{5)}$ および水銀圧入法の原理 ${ }^{5,6)}$ を参考にして，水銀で刻みの表面を一様に被いその排除 体積を测定する方法で見掛け密度の測定を行ったので， その結果をまとめた。

\section{2. 実験}

\section{1. 試 料}

試料は,たばて刻みの主原料である黄色種たばこ（Tobacco A)とバーレー㮔たばこ(Tobacco B)の 2 種類及 びシート状に成形した再生たばで7を用いた。

標準の見掛け密度を定めるために, たばて葉の主・支
脈を除いた葉肉部加ら葉片 $(45 \times 45 \mathrm{~mm})$ を採取し，また 再生たばこについては正常な部分から同じ大きさの試験 片を採取した。

刻みについては，同様の方法で選択した葉片又は試験 片を $0.8 \mathrm{~mm}$ 幅に, 到み用裁刻機を用いて裁断し, 試料之 した。

これらの試料を温度 $22^{\circ} \mathrm{C}$ ，相対湿度 $60 \%$ の条件下で 調湿し, 测定に供した。

なお，表面及び切断面の走查形電子顕微鏡写真を図 1 に示す。Tobacco BはTobacco A とほぼ同様であった。

2.2. 測定装置及び方法

2.2.1. 標準法と仮定した単位面積重量, 厚さ测定に よる方法

単位面積重量と厚さを測定し，その結果から見掛け密 度を算出する方法は最も簡便である。

しかし，たばこ葉の場合は大きい主・支脈は除いたと は言え，細網脈があり，葉の表面には凹凹がある。した がって, 試験片の厚さの测定が重要である。一般に, 紙 の厚さ測定に用いるダイヤルゲージではその測定機構 から大きい值となり、また切断面を顕微鏡で測定する方 法は精度は高いが, 試験片を切断するため他の測定に再
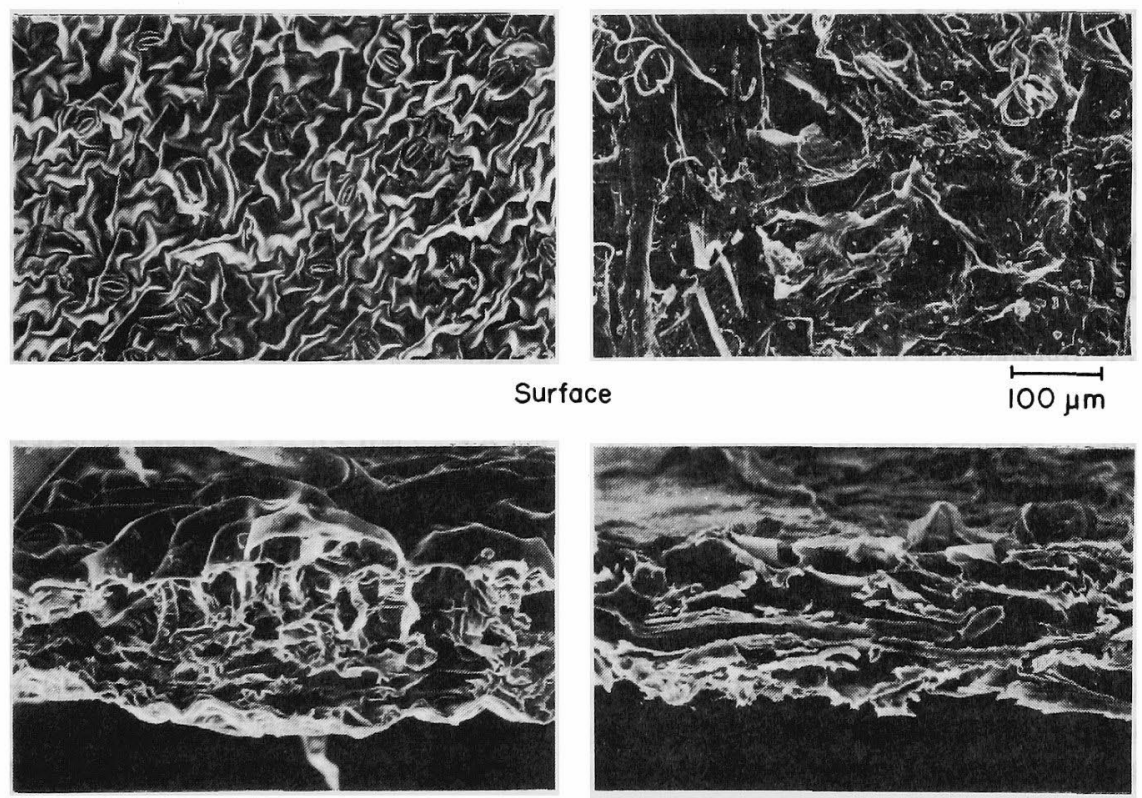

Cut cross-section

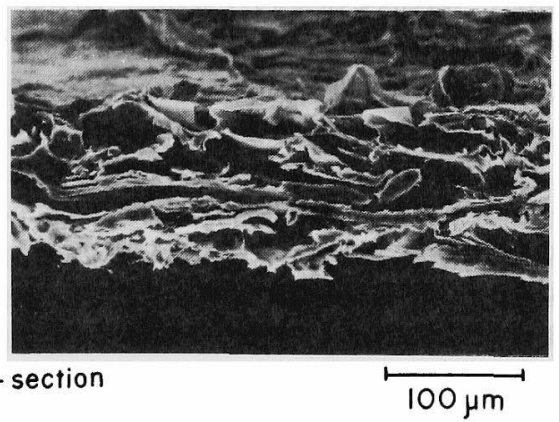

Tobacco A

Reconstituted tobacco

Fig. 1 Scanning electron micrographs of surface and cut cross-section of tobacco A and reconstituted tobacco 
使用できない次点がある。そてで，顕微鏡法とはは同じ 值が得られ、試験片を貱烄しないで測定できる非接触形 の北学式厚さ棓 ${ }^{8}$ 老用いた。これは同一北軸上の対称位 貿にある二双の顕微鏡により試料の雨面に焦点を合わせ， 焦点間の移動距離を厚さししてダィヤルゲージの目盛 (1/100 mm)を読み取る万法である。

この方法により各試料について試験片 10 片のそれぞ れ100筒所在測定してその平均值を代表值とした。また， 单位面積重量は試験片 30 片の重量を测定してをの平均 值索求如た。

\subsection{2 水銀法に上る測定}

水銀法に上る測定装置は図2 亿示すように、デシケ一 ター(1)，試料セル(2)，真空ポンプ(4)，緩衝容器(5)、水銀 マノメーター6，水銀留(7)加らる。な找，之れらの間 はニードルバルブ(A)放ガラス製コック(B)〜(D)で連結し た。試料セルは容積約 $25 \mathrm{~cm}^{3}$ のアクリル樹脂製セルを 用いた。
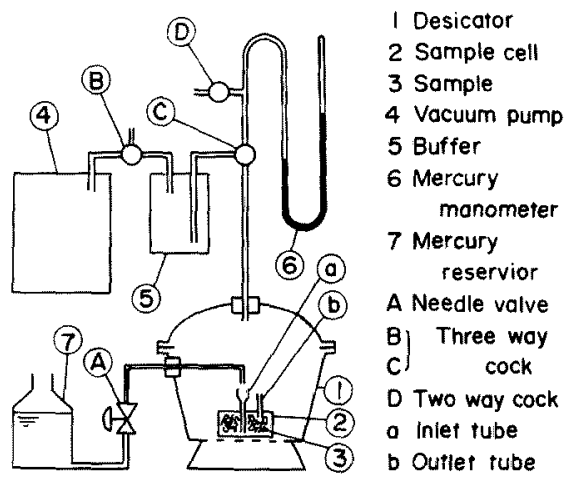

Fig. 2 Apparatus for measuring volumes by mercury displacement method

测定方法は，試料 0.5 3 $\mathrm{g}$ を入れたせルをデシケータ 一内に取容し，デシケーター内を真空にする(脱気時間 5 分間，真空度は $3 \sim 7 \times 10^{-1} \mathrm{mmHg}$ 汇到達)。次いで， ニードルバルブの在開き，水銀溜中の水銀をセルに供給 するが，水銀は大気在によってセルの唭用細管@に流 入し，セ山内を満たす。水銀が七ル内に充満すると三方 コック(C)切り替えて真空ポンプへの経路を閉じた後， コック(D)をわ゙かに開いて真空度を調節してマノメータ 一の水銀柱の差を所定值にして刻みへの水銀の压力を一 定にした後水銀の供給を停止する。その間，供給過剩の 水銀はセルの排出用細管(b)加らセル外へ流出する。それ

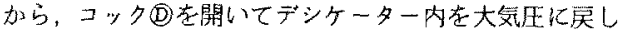
てセルの重量を秤量する。

供試試料の見掛り密度 $\left(\rho_{\mathrm{a}}\right)$ は (1) 式に上り，試料の見
掛け体皘 $\left(V_{\mathrm{S}}\right)$ と供試重量 $\left(W_{\mathrm{S}}\right)$ 加ら算出する。見掛け体 棈は，七ルに水銀のみ在満たした時の重量 $\left(W_{M}\right)$, 陚料 を入れて测定した時の重鼠 $\left(W_{\mathrm{T}}\right)$ ，供試試料重量及び水 銀の密度 $\left(\rho_{\mathrm{M}}\right)$ 加占求める。

$$
\rho_{\mathrm{a}}=\frac{W_{\mathrm{S}}}{V_{\mathrm{S}}}=\frac{W_{\mathrm{S}}}{\frac{W_{\mathrm{M}}-W_{\mathrm{T}}+W_{\mathrm{S}}}{\rho_{\mathrm{M}}}}
$$

\section{2 .3 油含漫法}

本法と比較のため油含浸法 ${ }^{1)}$ による測定を行った。 その測定法の概要について述べると，油含浸法では試 料を真空用油中に浸湏して20 分間减厓（真架度 $\times 10^{-2}$ $\mathrm{mmHg}$ )《保ち，試料緗孔内の空気を排除して油で置換 する。をの後，試料を取り出して表面の過剩の油層を遠 心除去(遠心效果は刻みで $300 \mathrm{G}$ ，シート状で 470G) L た後，之の重量夌測定し，增加した重量之真空用油の密 度加ら細孔容棈を求める。また，別に空気比較式比重計 (東芝ベックマン社慗，930形）で真密度在測定して，供 試試料の害体積を求め，細孔容皘，供試重量加見掛け 密度を算出する方法である。

\section{3. 結果及び考察}

\section{1. 水銀法の操作条件の検討}

\subsection{1. 测定王力の影暗}

まず，標準法での結果として単位面積重量，愿さ及び 测定時水分は，Tobacco Aでは $73.0 \mathrm{~g}-\mathrm{W} . \mathrm{M} / \mathrm{m}^{2} ， 0.12$ $\mathrm{mm}, 12.9 \%$ W.B.であり, 以下同様にTobacco Bは 30.4 $\mathrm{g}-\mathrm{W} . \mathrm{M} . / \mathrm{m}^{2} \quad 0.06 \mathrm{~mm}, 9.9 \%$ W.B.，再生たばこは 50.3 $\mathrm{g}-\mathrm{W} . \mathrm{M} / \mathrm{m}^{2} .0 .09 \mathrm{~mm}, 13.4 \%$ W.B.であった。是撕け密 度の値は表 4 亿示す。

水銀法に上る測定の場合，测定時の状態は，試料表面 を水銀が一様に被った状態で容積を湘定することが望ま しい。しかし，水銀は表面張力が大きく，試料の刻みは 加らみって塊状となっているので上記の条件を満たす ためにはある一定の止力を加える必要がある。この加え る圧力と容皘変化の関係について测定した結果を図 3 に 示す。压力と比容䄼の関係を示したが，压力が増加する にしたがって見卦け此容皘は減少し，生力200〜300 $\mathrm{g}-\mathrm{f} / \mathrm{cm}^{2}$ の範国では見挂り比容樍の変化はごくわずか で、また压力 $250 \mathrm{~g}-\mathrm{f} / \mathrm{cm}^{2}$ での傎は標染值とした単位面 皘重量・厚さ測定法の結果とよく一致した。とのとと加 ら，水銀法での压力の標準を $250 \mathrm{~g} \mathrm{-f} / \mathrm{cm}^{2}$ が啇当であ

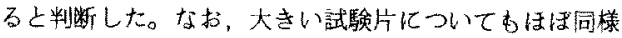
の結果加得られた。

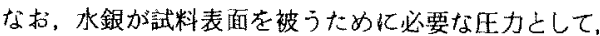
水銀ポロシメーターに上る Juholaらのガラス球(6〜8

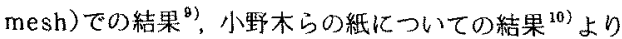




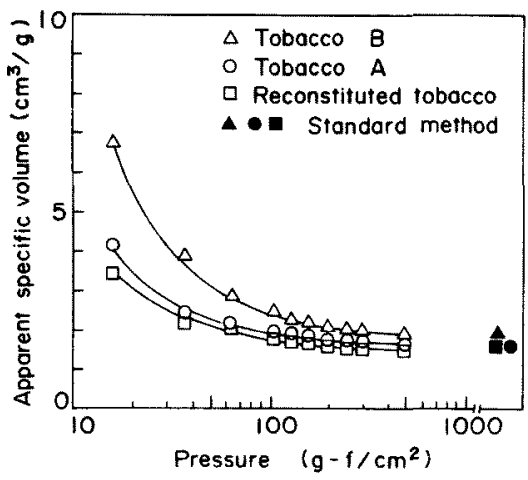

Fig. 3 Effect of mercury pressure on the apparent specific volume of samples

低い巨力である。それは，水銀が試料表面を被うたか心 王力に関係するたばこ刻みの表面の凹凸は，粗い紻維の 集合体である紙及びガラス球に比べて大きいとと，また 細長い刻みの接触によって二次的に形成される微小な空 間はガラス球，紙の場合より大きいことによるものと考 えられる。

次に，正力上水銀加浸入する細孔烽について検討す る。水銀は表面張力が大きいので刻みの組織内細孔に水 銀が浸入するには圧力が必要であり，その代力と円形の 細北径との関係はE.W.Washburn ${ }^{11)}$ が提唱した(2)式 の関係が成立する。

$$
\begin{aligned}
p=\frac{-2 \sigma \cdot \cos \theta}{r \cdot g_{c}} \\
\text { ただし, } \quad p: \text { 压力 } \\
\sigma: \text { 水銀の表面張力 } \\
\theta: \text { 水銀と固体の接触角 } \\
r: \text { 細孔半径 } \\
g_{\mathrm{c}}: \text { 重力換算係数 }
\end{aligned}
$$
$\left\{\right.$ dyn $/ \mathrm{cm}^{2}$ \}

$[\mathrm{cm}$

$$
\left(\mathrm{g}-\mathrm{mass} \cdot \mathrm{cm} / \mathrm{g}-\mathrm{f} \cdot \mathrm{sec}^{2}\right)
$$

そこで、設定した死力と細孔徍の関係を試料の細孔の 構成状態につき検討した。まず，ポリプロピレン製の細 管を用いて，毛細管に水銀が浸入する時の水銀柱の高さ から压力と紐孔径の関係を検討した結果在 4 亿示す。 はお，水銀の表面張力及び固体之の接触角は水銀ポロシ メーターで多く採用されている值(表面張力 $480 \mathrm{dyn} /$ $\mathrm{cm}^{2}$ ，接触角 $\left.140^{\circ}\right)^{6)}$ を用いた。結果は図4 K示し たように(2)式によく一致し，用力を定めると水銀が浸 入し得る細孔径が定まり，それ以下の勫孔には浸入し得 ないととを示した。したかっって，本法では測定圧力を $250 \mathrm{~g}-\mathrm{f} / \mathrm{cm}^{2}$ 亿定めたてとから，刻み表面に通ずる細孔 烽 $60 \mu \mathrm{m}$ 以上の細孔に水銀が浸入することになる。この

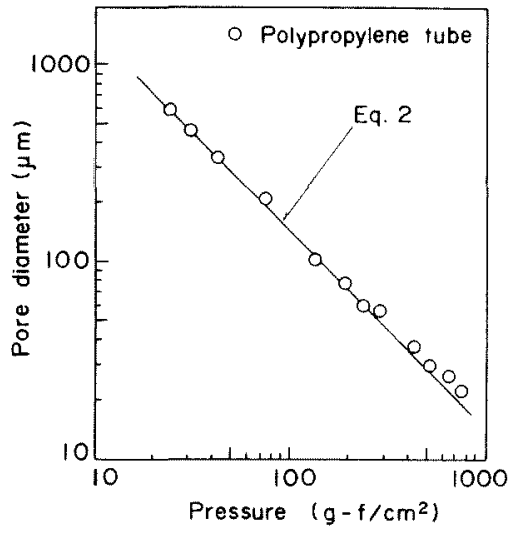

Fig. 4 Relationship between pressure and pore diameter on the mercury penetration

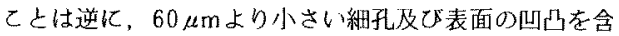
めた窓積を測定していることになる。

次いで，測定压力での水銀漫入に関係する試料の切断 面の細孔について，顕微鏡写真加ら細孔の周辺長上面積 老測定して求めた撸算直径を細孔径として表現すると，

Tobacco Aで $39 \mu \mathrm{m}$ ，Tobacco Bでは $35 \mu \mathrm{m}$ ，再生た ばてでは $44 \mu \mathrm{m}$ であった。この換算直径は再生たばこが たばて葉よりやや大きい值を示すが，各試料しも測定开 力で水銀が浸入する細孔径 $60 \mu \mathrm{m}$ 上り小さい。したがっ て，测定开力条件では組織内空隙に水銀が浸入しない上 推定される。

また，測定压力条件下での試料の正縮による変形につ いて検討してみた。測定が容易であるので試料の厚さに つて测定条件と同じ王力を加测定したとてろ, 压力 を加えない場合とはば近い值肪得られたので変形の影鄉 はないと考えられる。

\section{1 .2 供試量と刻みの大きさの影暃}

まず，供試量が 0.5 3g の範囲，すなわちかさ密度上 して $0.02 \sim 0.12 \mathrm{~g} / \mathrm{cm}^{3}$ の範国で供試量の多少が測定值に 及ぼす影響を検討した結果を表 1 亿示す。な扔，供試量 $3 \mathrm{~g}$ は用いた試料せルでの最大粗充てん量に相当する。 その結果，供試量が增加するにしたがってわずかに測定 值は大きくなる倾向にあるが，測定精度加らみて見脚け 比容皘として有意な差とは認められない。との結果加ら 供試量の多少に伴う刻み間の接触に上る影響は無視でき るものと考えられるし，供武量としては測定精度，試料 セルへの充てん操作の難易加ら判断して $1 \sim 2 \mathrm{~g}$ の籍讲 意適正量と䓔えた。

次に，刻みの大きさによる影響を検討するために，刻 みをふるい分りて測定した結果を表 2 に示す。そり結果， 
Table 1 Effect of sample weight on apparent specific volume

\begin{tabular}{ccccc}
\hline \multicolumn{5}{c}{$\begin{array}{c}\text { Apparent } \\
\mathrm{cm}^{3} / \mathrm{g}-\text { W. M. }\end{array}$} \\
$\begin{array}{l}\text { Sample } \\
\text { weight } \\
\text { g-W. M }\end{array}$ & \multicolumn{5}{c}{ Tobacco A } & Reconstituted tobacco \\
& Mean & $\begin{array}{c}\text { Standard } \\
\text { deviation }\end{array}$ & Mean & $\begin{array}{c}\text { Standard } \\
\text { deviation }\end{array}$ \\
\hline 0.5 & 1.72 & 0.02 & 1.60 & 0.03 \\
1.0 & 1.77 & 0.04 & 1.62 & 0.01 \\
2.0 & 1.78 & 0.01 & 1.65 & 0.02 \\
3.0 & 1.78 & 0.01 & 1.66 & 0.01 \\
\hline
\end{tabular}

Table 2 Effect of sample size on apparent specific volume

\begin{tabular}{ccc}
\hline Size ${ }^{* 1)}$ & $\begin{array}{c}\text { Sample } \\
\text { Screen opening } \\
\text { mm }\end{array}$ & $\begin{array}{c}\text { Apparent specific } \\
\text { yolume } \\
\mathrm{cm}^{8} / \mathrm{g}-\text { W.M }\end{array}$ \\
\hline $\mathrm{a}$ & $>4.00$ & 1.76 \\
$\mathrm{~b}$ & $4.00 \sim 2.00$ & 1.75 \\
$\mathrm{c}$ & $2.00 \sim 1.00$ & 1.80 \\
$\mathrm{~d}$ & $1.00 \sim 0.84$ & 1.80 \\
$\mathrm{e}$ & $0.84 \sim 0.71$ & 1.78 \\
$\mathrm{f}$ & $0.71 \sim 0.59$ & 1.70 \\
\hline *1) Prepared by screening of shreds (tobacco A)
\end{tabular}

ふるい目開き $0.71 \mathrm{~mm}$ 以上の粒度区分の测定値では有意 な差は譛められないが，0.71 $\mathrm{mm}$ 以下では見掛け比容積 は小さくなる傾向が認められる。これは刻みが小さい場

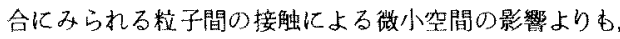
刻みが小さくなるととによってそれまでの内部空間が水 銀と接触する面となり，比表面皘に比して内部空間が减 少するためと考えられる。また，棒用上 $0.71 \mathrm{~mm}$ 以下の 刻みはほとんどないのでその影響は然視できると言える。

\section{1 .3 測定中の水分変化の影響}

本法では試料を娍开下に保持するために水分変化が生 じる。したがって，それに伴う乾燥収縮に上る見猢容 皘の変化が考えられるのでとれについて检討した。なお， そのときの乾燥による重量変化の影梪は供試量上その含 水率の変化量加らみて小さく，無視できると見なした。 そこで，初期水分として温度 $22^{\circ} \mathrm{C}$ ，相刘湿度 $60 \%$ に調 湿した刻みと減压乾燥しはとんど水分がないものについ て測定した結果を表 3 に示す。なお，見掛け比容積は測 定時の重悬基準とした。

表 3 の結果加ら乾燥した各試料の見掛比容積は調湿 品と有意な差は想められず，ほぼ同じ值を示す。しかし， 同一水弥にして比較するよ，すなわち調湿品について含 水率に相当する重量と容皘老坚純計算して水分のない状 態での見脚け比容皘を求めてみると，减生乾燥品より值
Table 3 Change in apparent specific volume by moisture content

\begin{tabular}{|c|c|c|}
\hline Sample & $\begin{array}{c}\text { Apparent specific } \\
\text { volum } \\
\mathrm{cm}^{2} / \mathrm{g}\end{array}$ & $\begin{array}{c}\text { Moisture } \\
\text { content } \\
\text { of W. B. }\end{array}$ \\
\hline \multirow[t]{2}{*}{ Tobacco $A^{* 1)}$} & 1.77 & 12.9 \\
\hline & 1.74 & 0.7 \\
\hline \multirow[t]{2}{*}{ Tobacco $B^{* 2)}$} & 2.09 & 9.9 \\
\hline & 2.08 & 0. \\
\hline \multirow{2}{*}{$\begin{array}{l}\text { Reconstituted } \\
\text { tobacco }\end{array}$} & 1.60 & 13.4 \\
\hline & 1.63 & 0 \\
\hline
\end{tabular}

は大きく，减压乾燥により4〜8\%程度の收縮となる。し たがって，調湿品を供試する場合は乾燥収縮に上る容皘 変化が考えられ，乾燥に上る取縮の大きい試料及で脱気 時間の変更については注意を要する。しかしながら，本 法での所要時間は約 10 分間と短く，その間の水分変化 は試料によって異なるが，表 3 に示す温度 $22^{\circ} \mathrm{C}$ ，相対 湿度 $60 \%$ での含水率では 4〜6\% W. B. の堿少であり，水 分変化に上る重量及び容皘への影響は小さく，寒用的に は問題ないと考艺られる。

\section{2 水銀法の標準条件での測定結果}

上記操作条件の検討加ら定如た標準条件，すな⿰ち水 銀压力 $250 \mathrm{~g}-\mathrm{f} / \mathrm{cm}^{2}$ ，試料量 $1 \sim 2 \mathrm{~g}$ として本法による 水銀法で見掛り密度を测定し，また従来法の油含浚法及 び標集法と見なした万法での結果と比較した。その結果 を表 4 に示す。

水銀法による刻みの見掛け密度は，たばこ暮について は梅準とした策位面䅧重量 厚さからの測定法及び油合 浸法の結果とよく一致するが再生たばこではやや大きい 值を示した。しかし，测定精度として平均值に対する標 準偏差の割合 (\%，測定 5 回)で示すと，油含浸法が 3.2 \%，水銀法が 27 \%であり，再現性に有意な差は認めら れ机。

なお，本法での再生たばての值が大きい值を示した原 因として表面状態の影響が考えられる。すなわち、㘠1 加ら屯観察されるように，切断面については両者に大き な相違はない。しかし，たばて葉の表面は破壊された表 皮細胞が汪とんど認められず，四凸はあるが連続した表 面状態を示しているのに対し，再生たばてはその製法か らたばこ葉の織維買を湿合皘層しているため，表面は絊 維自体の凹凸に加えて維間の陌閴があり複維な形と なっている。また，透気度 ${ }^{12)}$ 測定結果ではたばて葉の $2650 \mathrm{sec} / 100 \mathrm{ml}$ に対して再生たばては $18 \mathrm{sec} / 100 \mathrm{ml}$ と小さく，再生たばとの場合は空気は組織を容易に通過 し、湅孔は雨面間を相互連絡しているととがわかる。し 
Table 4 Comparison of apparent density and required time for measurement

\begin{tabular}{|c|c|c|c|c|}
\hline & & \multicolumn{2}{|c|}{ Method } & \multirow{2}{*}{$\begin{array}{l}\text { Standard } \\
\text { value }\end{array}$} \\
\hline & & $\begin{array}{c}\text { Mercury } \\
\text { displacement }\end{array}$ & $\begin{array}{c}\text { Oil } \\
\text { impregnation }\end{array}$ & \\
\hline \multirow{4}{*}{$\begin{array}{l}\text { Apparent density } \\
\left(\mathrm{g}-\mathrm{W} . \mathrm{M} . / \mathrm{cm}^{\mathrm{s}}\right)\end{array}$} & & (Shreds) & (Shreds) & (Sheet) \\
\hline & Tobacco A & 0.56 & 0.58 & 0.59 \\
\hline & Tobacco B & 0.48 & 0.47 & 0.47 \\
\hline & Reconstituted tobacco & 0.63 & 0.56 & 0.58 \\
\hline \multicolumn{2}{|c|}{$\begin{array}{c}\text { Required time for measurement }{ }^{* 2)} \\
(\mathrm{min})\end{array}$} & 15 & 50 & \\
\hline
\end{tabular}

*1) Calculated from weight per unit area and thickness.

*a) Mercury displacement: evacuating (5 min) - charging mercury $(5 \mathrm{~min}$ ) - adjusting pressure and recharging mercury ( $5 \mathrm{~min}$ ).

Oil impregnation: evacuating and penetrating oil (20 min) - separating sample from oil $(5 \mathrm{~min})$ - centrifuging excess oil $(10 \mathrm{~min})$, and measuring true density (15 min).

たがって，再生たばての複雑な表酒煹造と細孔径がなば と葉より大きいととから水銀が浸入する細孔がわずかに 存在し，標準値よりやや大きい值宗したと考えられる。

\section{3 従来法との測定方法の比較}

水銀法上油含漫法の簡便さ在所要時間上测定操作の特 性加ら比較すると，表 4 亿雨方法の1 点の測定所要時間 を示すように，水銀法は油含浸法の約 1/3 以下となり， 時間を大幅に短縮できる。

また，測定操作の特性としていずれの万法も熟練を要 する操作はないが，水銀法ではセ儿に試料を収容してか ら水銀を灌たしてをの重量を秤量するまでは試料の移動 はなく，测定操作约簡篻である。なお，水銀は毒性物質 であるため真空ポンプの排気及び測定後の試料なよ゙の取 扱いには十分注意在要する。それに対して油含浸法では 含浸徭油中加らの試料の取出し，遠心分離のために試料 を異なる容器に移動しなければならず，また粒度の小さ い刻みもあるためその操作に時間を要するととになる。

したがって，水銀法は簡単な装崖により簡便にしかも 実用的に他の万法と同等の測定精度でたばて刻みの兒掛 け密度を測定するととができる。

\section{4. 結論}

たばこ刻みの見烓け密度を留便に測定するために，水 銀の表面張力が大きい性質を利用した测定方法を検討し， 以下の結果を得た。

1）水銀の压力の增加にしたがって刻みの見掛け比容 積は减少するが、代力が $200 〜 300 \mathrm{~g}-\mathrm{f} / \mathrm{cm}^{2}$ の範用では はは一定值を示し，その見斯密度は彷来法と一致した。 その結果加ら測定厘力を $250 \mathrm{~g}-\mathrm{f} / \mathrm{cm}^{2}$ とした。
2) E力 $250 \mathrm{~g}-\mathrm{f} / \mathrm{cm}^{2}$ では直径 $60 \mu \mathrm{m}$ 以下の凹凸及 び紐孔には水銀が浸入し得ないととを確かめた。また， 通常の刻みには $60 \mu \mathrm{m}$ 以上の細孔は認めら扎なっった。

3）測定法として従来法の油含浸法と比較すると、精 度はほぼ同じで，測定所要時間は約 15 分間であり，油 含浸法の約 $1 / 3$ である。

4) 操作条件として王力 $250 \mathrm{~g}-\mathrm{f} / \mathrm{cm}^{2}$ ，試料量 1 ～ $\mathrm{g}\left(25 \mathrm{~cm}^{3}\right.$ 容試料セル)で, 通常の粒度分布を皇つ刻み に対して，本方法は正確に測定することができる。

付記：本研究は㵶維学会昭和 55 年年次大会に扔いて 発表した。

\section{文献}

1）增尾裕，片山良徳，篠㱦松巧；専売中研報，114， 17 (1971)

2) JIS P 8118

3) TAPPI Standard, RC method 256

4) D. L. Taylor; Tappi, 47, 165A (1964)

5) 河添邦太郎, 池田憲治；化学工学，26，1101 (1962)

6）浦野紘平; 表面， 13，588（1975）

7）片山良德，扣藤 䘚。清水幸夫，清水二郎；維学 誌，35，T-119（1979）

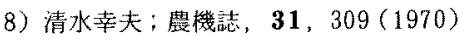

9) A. J. Juhola, E. O. Wiig; J. Amer. Soc., 71, 2078 (1949)

10）小野木康治，山内龍男，村上浩二，今村力造；紙 八技協誌，28，99(1974)

11）近藤連一編著；「多孔材料」，博報堂， p. 45（1973）

12) JIS P 8117 